\title{
Political Structure of the Khasis: With special reference to the Nongthymmai Dorbar Pyllun
}

\author{
Mrs. Monica. N. Laloo \\ (MA, M.Phil, Sociology)
}

\begin{abstract}
Over view of the Khasi traditional political structure: Traditionally, the political structures of the Khasi States were basically democratic and functioned independently and there was no centralised structure. The evolution of Syiemship can be attributed to the vital role played by the Basans and Lyngdohs to transform the society, which still continues and is practiced in this land (H Bareh, 1997: 234). These Basans and Lyngdohs hailing from the founding clan, are responsible for creating, the Syiemship in the context of the Khasi Hima (traditional states or early states). These states were governed by a Dorbar presided over by the chief, the representatives of the ruling families and villages within the state. The Dorbar Hima or the state council was the supreme authority. The council consisted of the Syiem, Ki Bakhraw i.e. the Lyngdohs, the Basans, the Dalois, and the Pators including representatives of the 'Raid' and of the village councils. The chief convened the Dorbar and acts as its president and the meetings were usually held in his sister's house i.e. Iing Syiem or Iing Sad and not in his wife's house nor in the market place. In the folklorist traditions of Khasi-Jaintia such 'Ka Li Dohkha and Ka Pah Syntiew, 'indicates that the origin of some clan and Syiem or chief of the Sutnga and of the Shillong Syiems respectively (Bareh, 1997: 44-68) was traced back in the past and the identity in essence is embodied in a woman. As Khasi people did not have a centralised political system, the political units were entirely independent of each other and were ruled by chiefs known as the Syiem, along with the support of this Myntris.
\end{abstract}

The Dorbar: The Dorbar Hima or the state council was the supreme authority. The council consisted of the Syiem, Ki Bakhraw i.e. the Lyngdohs, the Basans, the Dalois, and the Pators including representatives of the 'Raid' and of the village councils. The chief convened the Dorbar and acts as its president and the meetings were usually held in his sister's house i.e. Iing Syiem or Iing Sad and not in his wife's house nor in the market place.At any level of the Dorbar i.e. Dorbar Hima (State Dorbar), the Dorbar Raid (regional Dorbar), Village Dorbar or Clan Dorbar, only the elected senior members attended. The tradition of the Khasi is that only the male members were allowed to attend the Dorbar Shnong even though at present there is relaxation. The Dorbar was concerned with providing directive for day-to-day administration and actually acts as the court to dispose of cases and inflict penalties upon wrong-doers. It implemented development schemes such as road and bridge making, provision of water supply, construction of stone monuments and imparted training in the art of self government. It saw to detection of crime and apprehension of culprits. It arranged election or deputation of representatives to State councils. It prescribed rules of conducts and because of the total village participation, it became itself a training ground in citizenship, welfare, oratory and even in the resumption of economic activities. It channelised different means of village education acquainting young men in warfare, dance, music, social service and specialisation in other subjects including the use and veterance in martial arts (Bareh, 1997: 225) The Khasi Dorbar Shnong can be compared to the Legislative and Judicial form of the present government. All the issues related to state matters and for its prosperity were discussed in the Dorbar Shnong. But after India attained independence, the powers of the Syiem and of the Dorbar Shnong were placed to function under the District Councils.

\section{Introduction:}

As mentioned above the Khasi Society is characterized by a local form of administration in the form of village council known as 'Dorbar Shnong.' This Dorbar Shnong is an assembly of all adult males which functions under an elected headman or chief called Rangbah Shnong. The Dorbar Shnong looks after the welfare of the people and takes charge of the customary practices and imposes discipline among its members.

It is through the kur or matri-clan participation that the political system developed among the Khasis. In time an ordered system was needed be it social or political due to the growth in size of the kur. In this society a kni or uncle assumes an important function. He is the sole decision maker and carries out the legal and religious rites in the Dorbar kur or clan Dorbar. In course of time a Lyngdoh who is a priest or Basan who is an elder from the original settlers in the state or Hima was elected in consultation with the elderly clan members to handle the oath of administration of the village known as the village Dorbar or Dorbar Shnong. A political unit comprising of adjacent Khasi villages known as Dorbar Raid or territorial tribal council was formed to 
strengthen the traditional political unit of the various shnong. One of the headmen or Lyngdoh would preside over this assembly of local villages. The function of this council was to settle both civil and judicial matters, alongside to settle boundary disputes between villages, looks after the land and forest of the Raid. Further, several Raid joined together to form the State or Syiemship where a chief was elected called Syiem, which later under his leadership formed the Hima Dorbar, this Dorbar has the power to legislate, adjudicate and execute the law. All the adult males attended and took part in the discussions of the Hima Dorbar.

\section{Evolution of Nongthymmai Dorbar Pyllun:}

With the increase in the growth of population of the kur Kharkongor, the clan claimed this area as their own. In 1872, they obtained permission for registration of this area under the Hain Manik the then Syiem of Hima Mylliem, as they were the first inhabitants of the place. In course of time the kur increased as well as the number of households within the area. Therefore the kur felt the need of a leader to administer the social and political sphere of the people. An elderly male member of the kur Kharkongor was nominated by the clan who was known as the Rangbah Kur. Aton Kharkongor was the first Rangbah Kur. This continued till the 1930's until the emergence of the Dorbar Shnong. Because of growth in the number of households due to inter marriages with other clans and settlements of other clans in Nongthymmai territory, there was a need for reorganization of the administrative management. In order to have a better administrative structure, elders of the Kharkongor clan reviewed the system and concluded that Rangbah Shnong instead of Rangbah Kur would be more effective system. From this time instead of Rangbah Kur covering the whole Nongthymmai area a Rangbah Shnong is appointed on the basis of nomination to look after the thirteen village councils within the original Nongthymmai area. The Rangbah Shnong was assisted by a council or a group of village elders. This form of administration continues till date.

Nongthymmai covers the following localities comprising of Nongkhyriem, Lawjynriew, Lumpyngngad, Lumsohphoh, Nongrim Hills, Rynjah, Lapalang, Pohkseh, Nongshilliang, Lumiawblot, Lumbatngen (Law-u-sib) and Lumdiengsoh (Motinagar). These localities are under one main body known as the Nongthymmai Dorbar Pyllun. The members of this Dorbar Pyllun are the Headmen of the twelve localities of Nongthymmai from which eight office bearers are elected. The Dorbar Shnong is considered to be a platform where people can voice their opinion and have an equal say in the various processes of the Dorbar Shnong.

\section{Structure of the Nongthymmai Dorbar Pyllun:}

Nongthymmai falls under ka Hima Mylliem which is divided into thirteen shnong. Shnong is referred to a village which is the smallest unit of organized human aggregation though extending beyond and bigger then a family or a household. The shnong is looked after by a village council and hence there are thirteen Dorbar Shnong within the Nongthymmai Dorbar Pyllun.

The Nongthymmai Dorbar Pyllun is a local form of governance which is a three tier system with the Nongthymmai Dorbar Pyllun at the highest level in which is headed by the President. The next level consists of the shnong which is headed by a headman called the Rangbah Shnong and the lowest level is the dong which is headed by a Rangbah Dong.

Characteristics of the Nongthymmai Dorbar Pyllun:

Nongthymmai Dorbar Pyllun is a general body which comprises of all the Rangbah Shnong and the Secretaries of the various shnong and looks after the welfare of Nongthymmai as a whole. The Executive Committee members of this Nongthymmai Dorbar Pyllun however comprise of 6 members and are as follows i.e. President/Chairman, Vice President, Secretary, Assistant Secretary, Treasurer and the Auditor. It is only the Rangbah Shnong who can become a member of this Executive Committee.

The term of the office bearers is 3 years from the date of selection of the office bearers. The Nongthymmai Dorbar Pyllun has to meet at least twice a year and can also meet more often when the need arises. The Nongthymmai Dorbar Pyllun can have a meeting if $1 / 3$ rd of the members are present. In case the meeting cannot be held due to less number of members present, the meeting can be adjourned. The decisions taken by the Nongthymmai Dorbar Pyllun will be based on a simple majority. If the result is equal then the President/Chairman can cast his vote and hence a decision is made. The Constitution can be changed with the recommendation or approval of the $2 / 3$ rd majority of the members of the Nongthymmai Dorbar Pyllun. Any Dorbar Shnong can withdraw its membership from the Nongthymmai Dorbar Pyllun by informing the President/Chairman and Secretary. Decision will be taken by the Nongthymmai Dorbar Pyllun after a thorough investigation.

The Nongthymmai Dorbar Pyllun receives its fund from the subscription of the Dorbar Shnong and others in the form of donations. 


\section{Characteristics of the shnong:}

Nongthymmai is divided into thirteen shnong. Each shnong is headed by a headman called Rangbah Shnong. Similarly the Rangbah Shnong is elected by the members of the respective shnong based on a consensus and unanimous decision. Previously when Nongthymmai was still under clan domination the Rangbah Shnong was always to be selected from a particular clan. However these days since there are a number of mixed communities residing in Nongthymmai the Rangbah Shnong does not have to belong to any particular clan.

There have been instances where there is nomination of more than one individual for the position of a Rangbah Shnong. In such a situation the Rangbah Shnong was elected by the people by ballot system. The Rangbah Shnong is assisted by an Executive Committee which includes all the Rangbah Dong. In each shnong there are two organizations namely (i) Seng Kynthei which is a woman's organization and (ii) Seng Samla which is a youth organization. However it is only in the Dorbar Shnong of Lumpyngngad, Nongshilliang, Nongkhyriem and Nongrim Hills where women are also members of the Executive Committee.

\section{Executive Committee of the shnong:}

The village council of the Dorbar Shnong is composed of all the Rangbah Dong. The Executive member is comprised of (i) Rangbah Shnong (ii) Assistant, Rangbah Shnong (iii) Secretary (iv) Assistant Secretary (v) Treasurer (vi) Publicity Secretary and (vii) Sports and Cultural Secretary. Others committees can be formed when the need arises. It is to be noted that in Nongthymmai, out of the thirteen shnong only four shnong that is Nongkhyriem, Nongshilliang, Lumpyngngad and Nongrim Hills where women are members of the Executive Committee.

\section{Characteristics of the dong:}

Dong is a smaller area which is situated within the shnong. A number of dong constitutes ka shnong. Dong is a unit which is part of the Dorbar Shnong. Dong is headed by the Rangbah Dong. The Rangbah Dong was elected by the members of the respective dong in the Dorbar Shnong itself. The election was based on consensus and unanimous decision. The Rangbah Dong is assisted by an Executive Committee of the dong.

Function of the Nongthymmai Dorbar Pyllun:

The Nongthymmai Dorbar Pyllun seeks to look after the welfare of Nongthymmai as a whole. It caters to the common issues of the people such as drinking water supply, electricity, in times of natural calamities and other such issues which includes towards looking after the welfare of the people and society as a whole.

\section{Function of the Nongthymmai Dorbar Pyllun are as follows:}

- The thirteen Dorbar Shnong shall work together to bring about peace and harmony in the society.

- To work together in times of disagreement or chaos within the Nongthymmai Dorbar Pyllun.

- The Nongthymmai Dorbar Pyllun shall not interfere in the administration of the various Dorbar Shnong but is willing to help the various Shnong in times of difficulties and in times of need.

- The Nongthymmai Dorbar Pyllun shall work along with the Government in matters relating to development of the shnong.

- To help the youth in education and employment as well.

The Nongthymmai Dorbar Pyllun looks after the common issues within Nongthymmai but it does not interfere in the internal matters of the thirteen Dorbar Shnong. However, each Dorbar Shnong works independently from one another and is headed by a Rangbah Shnong.

\section{Role of the Office Bearers:}

The office bearers of the Nongthymmai Dorbar Pyllun have various roles in order to bring about an effective system of administration within Nongthymmai.

\section{President:}

- To preside over the meetings held by the Nongthymmai Dorbar Pyllun and the meetings held by the Executive Committee.

- To sign the proceedings of the Nongthymmai Dorbar Pyllun and the proceedings of the Executive Committee.

- To convene an emergency meeting when required or if requested by the Nongthymmai Dorbar Pyllun as well as any Dorbar Shnong which falls within Nongthymmai.

\section{Vice President:}

- To help the President

- To take charge of the office of the President according to the norms in the absence of the President. 


\section{Secretary:}

- To record all the proceedings of the Nongthymmai Dorbar Pyllun.

- To sign the proceedings of the meeting held within the Nongthymmai Dorbar Pyllun along with the President.

- $\quad$ To call upon meetings of the Nongthymmai Dorbar Pyllun within an understanding with the President. The Secretary along with the President has to sign all the notices handed out to the various Rangbah Shnong within Nongthymmai.

- To hold cash up to an amount of Rs.1000/- for official work of the Nongthymmai Dorbar Pyllun and if any urgency arises he can ask from the Executive Committee of the Nongthymmai Dorbar Pyllun.

- To sign cheques along with the Treasurer if any money is to be withdrawn from the bank.

- To open an account along with the Treasurer in any bank.

Assistant Secretary:

- To help the Secretary

- To act as the Secretary in his absence

\section{Treasurer:}

- To keep records of the receipt and expenditure of the Nongthymmai Dorbar Pyllun.

- To sign cheques along with the Secretary if any money is to be withdrawn from the bank.

- To open account in any bank along with the Secretary.

- To hold money of Rs1000/- for official work of the Nongthymmai Dorbar Pyllun and if any urgency arises he can ask from the Nongthymmai Dorbar Pyllun.

\section{Auditor:}

- The Nongthymmai Dorbar Pyllun will elect a person who is a resident of Nongthymmai to be an auditor who is well versed in this field.

- The Auditor will audit once a year the receipt and expenditure of the Nongthymmai Dorbar Pyllun and report the same.

\section{Dorbar Shnong:}

In case of Dorbar Shnong it would meet annually but in case of an emergency the Dorbar Shnong could be assembled more often. A person who is a member of the Dorbar Shnong was to be present. Women attended the meetings of the Dorbar Shnong but however are not elected as members of the Executive Committee. It is only in Nongkhyriem, Nongshilliang, Lumpyngngad and Nongrim Hills that women are members of the Executive committee. The meetings of the Dorbar Shnong was presided by the headman. Each Dorbar Shnong functions independently and works for the common good of the people. The Dorbar Shnong also implements the various schemes which have been provided to them by the Government. It also looks after peace and prosperity amongst the people. The Dorbar Shnong is concerned with maintenance of law and order and acts as a mediator in cases of disputes between the residents. Besides this the Dorbar also takes up matters relating to the general welfare of the people. The Executive members of the Dorbar Shnong makes sure that there is complete transparency in matters relating with money, they provide an annual report of all the schemes along with the financial statement which is duly audited by the elected Auditors.

\section{Rangbah Shnong:}

The Rangbah Shnong is the representative head of the shnong and his responsibilities were diverse. He is responsible for the general well-being of the people residing in the shnong.

The Rangbah Shnong presides over the annual general assembly meetings as well as the Executive Committee meetings. He is assisted in the day-to-day administration by his team of office-bearers as well as the other members of the Executive Committee. His main objective is to look after the peace and serenity in the shnong. He is responsible for bringing about development by the schemes provided by the government. He has to supervise the implementation of the development schemes by the government and also by the local representatives of the constituency i.e., Member of Legislative Assembly Development Scheme (M.L.A. Scheme) and Member of District Council Development Scheme (M.D.C. Scheme). It is the Rangbah Shnong who issues No Objection Certificate to the non tribal's for setting up of businesses within the shnong, residential certificate are also issued by the Rangbah Shnong to verify that individuals are the residents of the shnong.

\section{Committee Dong:}

The shnong is further divided various Committee Dong to help them to look after the proper management. Therefore this Committee Dong act as smaller units to look after the welfare of the people and assists the shnong in achieving this. The Committee Dong usually meets four times a year and could be 
assembled whenever any emergency arose in the dong. All matters relating to the welfare of the dong were discussed in the meeting. The Committee Dong works according to the guidelines of the shnong.

Likewise the dong tries to settle matters of disputes within the Committee Dong but if the matter cannot be solved it is taken to the Dorbar Shnong. Similarly if the Dorbar Shnong cannot settle the matter it is further taken to the Nongthymmai Dorbar Pyllun. Lastly if the Nongthymmai Dorbar Pyllun cannot come to any decision the matter is taken to the police and Court.

The Dorbar Shnong works together with the Committee Dong to bring about overall development and look after the welfare of the people. Therefore their functions can be placed together in the same categories. The functional aspects of the Dorbar Shnong are as follows:

Organizing festivals: Festivals are organized by the Dorbar Shnong in their respective Shnong annually for a week. The shnong organizes various traditional as well as western music and dance shows to show case the various talents of the youth in the society. Sports programmes are also held during such festivals. It is a time where the people within the shnong come together and interact and also a sense of solidarity among the people develops. For the women in the shnong food festival is held where women would cook various dishes and are sold to the people.

Maintenance of law and order: The main aim of the Dorbar Shnong is to look after the peace in the shnong. Every Rangbah Shnong seeks to maintain peace and solidarity among the residents of the shnong. For example, in the year 2011 there were many cases of theft in Nongthymmai. The various Dorbar Shnong decided to have night patrol in order to reduce down such instances. Members of the shnong would patrol the roads during the night to bring about a sense of security among the residents. There have been cases where people who are not residents of Nongthymmai would come and consume liquor within various parts of the shnong and create disturbances within the shnong. At such times the residents would inform the Rangbah Dong or the Rangbah Shnong, the headmen along with the members of the Dorbar Shnong would intervene and try to reason with such people and ask them to leave the premises. There are times if drunken people were found in the shnong either their families were contacted to take them or they were directly taken to the police.

To settle of boundary disputes: The Dorbar Shnong tries to settle any dispute regarding land or patta issues. However, there have been cases when even though the Dorbar Shnong have helped the people regarding settling of land disputes they decision stand null and void when the matter is taken to the court. The Dorbar Shnong also acts as a mediator in cases of disputes between the residents of Nongthymmai. Besides this the Dorbar Shnong also takes up matters relating to the general welfare of the people. The Dorbar Shnong assembles to look into matters of conflict between individuals from the same shnong. in cases where there is dispute between individuals from different shnong for example between Lawjynriew and Lumiawblot then the matter is discussed between the Dorbar Shnong of Lawjynriew and Dorbar Shnong of Lumiawblot. If the matter cannot be solved then it is taken to the Nongthymmai Dorbar Pyllun. There have been cases where outsiders who do not belong from Nongthymmai would create problems or brawls in the shnong and the residents inform the Dorbar Shnong. In such cases the Dorbar Shnong would inform the relatives of the concerned parties but in case the situation becomes tensed then the matter is at once taken to the police.

Water Supply: The Dorbar Shnong tries its best to provide water to all the households within the shnong. Since Nongthymmai is not under Shillong Municipal, it is the Public Health Engineering (PHE) who provides water to the various shnong. The PHE hands over the water management to the shnong. Hence it is the Dorbar Shnong which maintains and looks after the distribution of water to the residents.

Organizing funerals or cremation: The Dorbar Shnong help the residents when there is death in the family. In such situations the Rangbah Shnong informs all the Rangbah Dong to allot a youth from the dong to collect donation from each household in the shnong and the amount is given to the bereaved family. Further it the male youths from the shnong that helps the family to dig a hole for burial in the cemetery. In case of cremation the male youth helps to make the pyre in which the body of the deceased will be burnt.

Schemes: The Dorbar Shnong also implements the schemes that have been provided by the Government. Schemes provided by the Member of District Council (MDC) for constructions of pavements or roads are handed to the Dorbar Shnong. The Dorbar Shnong of Lumsohphoh implements the schemes by giving the construction work to the unemployed youths of the shnong and thus providing them with some sort of income.

Social activities: Free medical camps are also organized by the Dorbar Shnong from time to time to help and give proper medical treatment for the people in the shnong. In Nongrim Hills, the Dorbar Shnong has set up a clinic in the evening in order to help the residents. Doctors from the shnong are requested to provide their service on such occasions. A crèche was set up in Lawjynriew in order to help the working mothers of the shnong. Mother's could leave their children in the day care centre with the presence of a care taker and earn their living. Therefore it is worthwhile to know that the Dorbar Shnong recognizes the importance and the contribution of women in the society.

Collection of taxes: The various Dorbar Shnong collects monthly taxes from each household which is used for various purposes such as maintaining of street lights, water, drainage, waste disposal etc. 


\section{Sixth Schedule and Traditional Institutions:}

The administration of the tribal areas in the North-Eastern Region were earlier known as 'backward tracts', which has a history of its own and can be traced back to British rule. The grant of Dewany of Bengal to Robert Clive in 1765 secured for the East India Company "superintendence of all laws and the collection of all revenues" in the Presidency of Bengal (Hansaria, 2005:1). The making of laws was entrusted to the GovernorGeneral in Council by the Government of India Act, 1853 prior to the taking of the government of the territories which was formerly administered by the East India Company by the British sovereign in 1858 . Following the Sepoy Mutiny of 1857, the Governor-General in Council was empowered to make laws and regulations by the Government of India Acts of 1833 and 1853.

The Government of Indian Act, 1870 gave the Governor-General the authority to legislate separately for the backward tracts. This act was extended to the Assam Valley, Hill Districts and Cachar with effect from 1.1.1873. On the $6^{\text {th }}$ February 1874, Assam was put under a Chief Commissioner by taking away its management from the Lt. Governor of Bengal. The same year in April, the Scheduled Districts Act, 1874 was enacted and hence the entire Chief Commissioner of Assam was declared to be Scheduled District. The term 'Scheduled Districts' was understood to mean " those remote or backward tracts or provinces of British India which had never been brought within or had from time to time been removed from the operation of the general Acts and Regulations and jurisdiction of ordinary courts or in which that operation was not complete, and officers were supposed to be guided by the spirit of indispensable laws or were actually guided by such laws had somehow or the other been considered to be in force" (Hansaria, 2005:3).

Matters relating to administration of these areas were then thought out (considered) in the MontaguChelmsford Report of 1918. The report contended that certain backward areas which reforms could not be applied and these regions should be administered by the Governor. Political reforms could not be applied to these regions as the people were still primitive and there was no way in which political institutions could be set up. Hence the Government of India Act, 1919 was enacted through which the Governor-General may declare any territory in British in India to be a backward tract. The Government of India Act, 1935 gave up the term 'backward tracts' and instead described them either as 'excluded areas' or 'partially excluded areas'.

Part I: Excluded Areas should comprise North-East Frontier, Sadiya, Balipara and Lakhimpore, the Naga Hills District and the Lushai Hills District

Part II: Partially Excluded Areas should comprise North Cachar Hills in the Cachar District, the Garo Hills District, the Mikir Hills in the Nowgong and Sibsagar Districts, the British portion of the Khasi and Jaintia Hills other than Shillong Municipality and the Shillong Cantonment (Lyngdoh, 1996:93).

The main aim of the administration at that time was static then dynamic and this insulation of administration lead to prolongation of backwardness of the North Eastern Region especially the areas which were largely inhabited by the tribal people. The British did everything to bring about emotional integration between the tribal people and the non-tribals and evolution of a common identity overriding ethnic diversities.

The Cabinet Mission, sent by the British Parliament under Sir Stafford Cripps had made a public statement on 16 March, 1946 which had also suggested for the formation of an Advisory Committee, to look into the rights of minorities and tribals of excluded area. For that reason, an Advisory Committee on fundamental rights, minorities and Tribal and Excluded Area was set up with Vallabhai Patel as the Chairman on 24th January, 1947 by the Constituent Assembly. The main task of the committee was to work out an approach in the constitutional arrangement for tribals of excluded and partially excluded area and to enable them to safeguard their ethnic identity and culture in a democratic way.

The makers of the Constitution acknowledged the requirement of a separate political and administrative structure for the Tribal Areas by enacting the Sixth Schedule to the Constitution of India which was broadly guided by the following considerations:

- The exigency of preserving the culture and tradition of the tribal people

- The need to provide autonomy in socio-economic and political affairs; and

- The necessity to prevent their exploitation by the more advanced people of the plains (Karna, 1998:128).

Following the recommendation by the Advisory Committee on the $2^{\text {nd }}$ February 1947, a sub-committee was set up. The chairman of the sub-committee was Gopinath Bordoloi and the others members were Rev.J.J.M. Nicholas Roy, Rup Nath Brahma, A.V. Thakkar and Mayang Nokcha. Mayang Nokcha replaced Aliba Imti, the previous member who was from Naga Hills. The committee was also popularly known as Bordoloi Committee after the name of its Chairman and the then Chief Minister of Assam, Gopinath Bordoloi. Even after partition of the country into India and Pakistan on 14 August, 1947 a sub-committee on North East Frontier (Assam) Tribal and Excluded Area Committee and Excluded and partially excluded areas in provinces other than Assam, continued to function.

The Bordoloi Committee submitted its report to Vallabhai Patel, Chairman of the Advisory Committee on 28th July, 1947. The report dealt with various aspects relating to administration of the tribal areas such as 
views on development, special feature of these areas, land, forest, control of immigration, service etc. The Advisory Committee discussed the report on 7th December, 1947 and 24 February, 1948. The Drafting Committee also studied the report on 13 February, 1948. BN Rau, Constitutional Advisor had put the report in the Sixth Schedule and after rearrangement Dr. B.R. Ambedkar, Chairman, Drafting Committee put the same in the Sixth Schedule.

The Draft Schedule was submitted to Dr. Rajendra Prasad, President of the Constituent Assembly on 21st February, 1949 and the matter was discussed in the Constituent Assembly on 5, 6 and 7 September, 1949. There was heated exchange of words between the supporters and opponents of the Draft Schedule. Rajeshwar Prasad from Bihar as well as Rohini Kumar Chaudhury and Kuladhar Chaliha from Assam were quite vocal in their opinions against the establishment of District Council under the draft Sixth Schedule. They firmly stated that, instead of guarantying autonomy, the hill areas should be assimilated with the plains. Kuladhar Chaliha had even alleged that in the like manner in which Pakistan was created, the Sixth Schedule would create Tribalistan which would be a great threat to national integration, However, Dr.B.R. Ambedkar, Gopinath Bordoloi, A.V. Thakkar, Jaipal Singh and Rev. JJM Nichols Roy spoke strongly in favour of the Sixth Schedule provision.

In the course of the heated debate in the Constituent Assembly, Rev. JJM Nichols Roy stated that there were different types of tribals and tribals of Assam were lovers of democracy. So, the proposed democratic setup would be convenient for them because they had already experienced such type of system from before. Over and above that Rev. JJM Nichols Roy also had submitted a memorandum to the Cabinet Mission, demanding the creation of a political set-up where the tribals would be able to govern themselves. Therefore, Rev. JJM Nichols Roy had enormously contributed in the genesis and emergence of Sixth Schedule to the Constitution of India. As a matter of fact, Rev. JJM Nichols Roy was regarded as an architect of the District Council autonomy.

After a long heated debate in the Constituent Assembly certain amendments were made, the Sixth Schedule finally emerged and was incorporated in Article. 244(2) read with 275(1) of the Constitution of India in the year 1952. Along with that, preservation of custom, culture, language and ethnic identity of tribals of Excluded and Partially Excluded areas other than Assam was incorporated in the Fifth Schedule in Article 244(1) of the Constitution of India.

The adoption of the Sixth Schedule to the Constitution of India provided for the establishment of the Autonomous District Councils (ADCs) in some hill districts of the erstwhile composite state of Assam. The entire state of Meghalaya was under the provisions of the sixth Schedule of the Constitution. There are three Autonomous district Councils in terms of the Sixth Schedule of the Constitution in Meghalaya:

- The Khasi Hills Autonomous District Council (KHADC) covers the districts of East Khasi Hills, West Khasi Hills and Ri Bhoi;

- The Garo Hills Autonomous District Council (GHADC) covers the districts of East Garo Hills, West Garo Hills and South Garo Hills; and

- The Jaintia Hills Autonomous District Council (JHADC) covers the Jaintia Hills.

\section{The relationship of the Nongthymmai Dorbar Pyllun and the District Council:}

Under sub-paragraph (g) of paragraph 3(1) of the Schedule, the District Council has been given the power to make laws in relation for the appointment or succession of the Chiefs or Headmen of the Dorbar. The District Council approves the sanad which has been given to the Rangbah Shnong by the Syiem of Mylliem.

The Rangbah Shnong also issues No Objection Certificate (NOC) to non tribals for setting up of businesses in the shnong for submission of trading license forms to the District Council. Trading license will not be issued by the District Council to any non-tribal without the NOC from the Rangbah Shnong. The NOC provided by the Rangbah Shnong to the non-tribals is a proof that they are residents of the Shnong and are not outsiders who do not reside within the premises of the Shnong. Such residential certificates are needed when an individual wishes to apply for a new phone or mobile connection, connection for electricity and opening of bank accounts. According to "Paragraph 10 of the Sixth Schedule the District Council of an autonomous district may make regulation and control of money-lending or trading within the district by persons other than Scheduled Tribes resident in the district" (Hansaria, 2005:70).

The power of the Rangbah Shnong is not officially recognized by the Government, though the Syiem gives the sanad as per the Sixth Schedule to the constitution of India.

The District Council has a close association with the shnong than the Dorbar Pyllun. The relationship between the Dorbar Shnong and the District Council is essential as the District Council relies on the Rangbah Shnong to provide certificates

The relationship between the District Council and the Dorbar however has not always been a pleasant one. For example, when the various Rangbah Shnong to provide a proof of residence for people for the application of mobile connections, acquiring of electricity connection and opening of new bank accounts; but at the same time when the residential certificate is provided by the Rangbah Shnong the District Council objects 
the certificate stating that such documents are not recognized by the Government and hence the District council cannot accept them as authentic documents since these traditional bodies are not a legalized body.

\section{The Relationship of the Nongthymmai Dorbar Pyllun and ka Hima Mylliem:}

As mentioned the Nongthymmai is under the Mylliem Syiemship. To uphold, strengthen its relation with the Dorbar the Syiem conforms to the advices and instruction given by the Myntri. These Myntris are elected by their clan and entitled to hold the office lifetime unless otherwise removed. The Syiem of Mylliem and the Nongthymmai Dorbar Pyllun have a close relationship as the sanad is approved and issued by the Syiem. The Syiem is the appointing is the appointing authority of the headman and hence the headman and his Dorbar are accountable to the Syiem. During the election of the Rangbah Shnong the Myntri of the Syiem act as observer on the request of the Dorbar and the Myntri will have to report to the Syiem. Whenever there is selection of new officers bearers of the Nongthymmai Dorbar Pyllun the Syiem have to be notified and recognizes the office bearers. If there is any change in the office bearers of organizations such as the Seng Kynthei the same should also be reported to the Syiem of Mylliem and the newly appointed officer bearers are again recognized by the Syiem.

\section{Ka Hima Mylliem, District Council and the Nongthymmai Dorbar Pyllun:}

So far information gathered from the office of the Syiem Hima Mylliem and Dorbar showed that under the Sixth Schedule to the constitution of India, Nongthymmai Dorbar Pyllun is under ka Hima Mylliem and Mylliem Syiemship is under the jurisdiction of the Khasi Hills Autonomous District Council. The relationship between the Syiem of Mylliem Syiemship with the Nongthymmai Dorbar Pyllun as well as ki Dorbar Shnong is that the Syiem and Dorbar of the Mylliem Syiemship issues an appointment order which is called "sanad" to the newly elected headman under Section-16 Clause-2 of the Khasi hills Autonomous District (Appointment and Succession of Chiefs, Deputy Chief Electors and Rangbah Shnong of Mylliem Syiemship) Act, 2007. It is the Executive Committee of the Khasi Hills Autonomous District legitimizes the position of the Rangbah Shnong under the provisions of the Sixth Schedule to the Constitution of India.

\section{Analysis on the Traditional Polity of the Khasi:}

The Khasi say 'war and politics is for men' and this can be clearly seen especially in the traditional system of the Khasi where men dominate in the political administration. Not only women were debarred from this areas but the whole political system itself is biased even towards men. Only the eligible clan and family can be the Syiem or chief or the minister, which means all the Khasi, cannot be the chief or be a representative to the state or council's members. This seems to be relevant with the other culture of India especially the practice among the Hindu i.e. the caste system and in fact it might have been that the Khasi borrowed this ideas since they had early contact with them. Thus to be the Syiem or chief one should belong to the Syiem clan and particular family of the ruling clan and that too only the male members; and to be a Myntri or the minister one should be from the priestly clan or the founding clan and too only male members and to be a headman in some places he should only be from the founding clan. This idea is purely patriarchal and going along with religion it strengthens elitism where the other citizen is considered as unfit or not entitled to a position. In spite of the fact, that religious preparation is arranged by women, yet they were not given an important place. Therefore to the Khasi in order to avoid or exclude women from being elected as the Syiem in the absence of male members to succeed the throne, they would choose the slaves.

Therefore the Nongthymmai Dorbar Pyllun is like a super structure which helps the various Dorbar Shnong, when the need arises. This Nongthymmai Dorbar Pyllun does not interfere in the management or administration of the thirteen shnong. It only takes up common issues between the various shnong and makes an assessment. It also looks into matters which any of the Dorbar Shnong cannot come to any decision or conclusion. Therefore each shnong works independently without any interference from the Nongthymmai Dorbar Pyllun.

\section{Conclusion:}

Even though this traditional system of administration i.e. Dorbar Shnong have been present since many generations, yet very little is known of how it actually functions. Most people are not aware that there exists a three tier system of this traditional administration. It is only the Executive Committee who has a clear understanding of how the Dorbar Shnong actually functions. In order for a more effective functioning of the Dorbar Shnong the people should be more aware of this traditional body.

The function each Dorbar Shnong within the Nongthymmai Dorbar Pyllun would vary from one shnong to the other. There is no uniformity in the functions and development of the thirteen shnong. Hence, if there was a unified system of laws which all the Dorbar Shnong followed then there would be an overall development and a consistent working of the Dorbar Shnong. 
If these traditional bodies were to be recognized by the Government it would be able to perform and implement rules more effectively. There would be a vast difference within the society. There would be an increase in regulation within the shnong. Societies these days are characterized by legitimized bodies and codified rules and laws but these traditional bodies do not have any uniformity or codified rules to make it a more effective system.

Each Dorbar Shnong would collect a monthly tax (ka fund shnong) from the residents of the shnong. However under Article 265 to the Constitution of India collection of such taxes is illegal except by law. Such laws laid down by the Government are not known or aware by the members of the Dorbar Shnong. Taxes are not collected by the Dorbar Shnong from the residents of Lumdiengsoh (Motinagar) as the residents pay an annual tax to the Government. Therefore this locality has no relationship with the Syiem of Mylliem but directly with the Deputy Commissioner. Surprisingly only four Dorbar Shnong have women in their Executive Committee i.e. Lumpyngngad, Nongshilliang, Nongkhyriem and Nongrim Hills. The question that arises here is to what extent are the Dorbar Shnong as well as the Nongthymmai Dorbar Pyllun democratic?

There is a close link between the Nongthymmai Dorbar Pyllun with modern institutions as various schemes provided by the Government have been implemented within Nongthymmai. The Dorbar Shnong works hand in glove with the Government to bring overall development through various schemes as well as maintaining law and order by working together with the police when the need arises.

[1]. Bareh, H. 1964. Khasi Democracy. Shillong: Ri Khasi Press.

[2]. Bareh, H. 1997. The History And Culture Of The Khasi People. New Delhi: United Publishers.

[3]. Chattopadhyay, S.K, ed. 1985. Tribal Institutions of Meghalaya. Guwahati: Spectrum Publications.

[4]. Chowdhury, J.N. 1998. Tha Khasi Canvas. Calcutta: Jeeta Offset.

[5]. Gassah, L.S. 1997. Autonomous District Council. New Delhi: Omsons Publications.

[6]. Gassah, L.S. 1998. Traditional Institutions of Meghalaya: A Study of Doloi and his Administration. New Delhi 110008: Published by Regency Publications.

[7]. Gurdon, P. G. 2002. The Khasis. New Delhi: Low Price Publications.

[8]. Gupta, P.K.D. 1989. Life and Culture of Matrilineal Tribe of Meghalaya. New Delhi: Inter-India Publications.

[9]. Hansaria, B.L. 1983. Sixth Schedule to the Constitution. New Delhi: Universal Law Publishing Co. Pvt. Ltd.

[10]. Jyrwas, E. 2006. Administration of Justice in the Khasi Hills. New Delhi: Akansha Publishing House.

[11]. Karna, M.N, Gassah, L.S, Thomas, C.J, ed. 1998. Power to the People in Meghalaya. New Delhi: Regency Publication.

[12]. Ladia, O.D.V. 1993. The Administration of Justice in Meghalaya. Guwahati: Published by Assam Law House.

[13]. Lyngdoh, R.S. 1996. Government and Politics in Meghalaya. New Delhi 110017: Sanchar Publishing House.

[14]. Mathur, P. R. G. 1987. The Khasi of Meghalaya: A Study in Tribalism and Religion. Delhi: Cosmo Publications.

[15]. Mawrie, H.O. 1981. The Khasi Milieu. New Delhi 110015: Concept Publishing Company.

[16]. Nongkynrih, A.K. 2002. Khasi Society of Meghalaya: A Sociological Understanding. New Delhi 110027: Published by M.L. Gidwani.

[17]. Rizni, S.H.M. and Shibani Roy. 2006. Khasi Tribe of Meghalaya. New Delhi: B.R. Publishing Corporation.

[18]. Rynjah, Sweetymon and Margaret B Challam ed. 1999. "The Khasi Family: Dynamic Role of Father and Maternal Uncle Family" in The Dynamics of Family System in a Matriliny of Meghalaya. Shillong: Director Arts and Culture Tribal Research Institute.

[19]. Rymbai, R.T. ed. 1975. Report of the Land Reforms commission for Khasi hills. Shillong: Government Press.

[20]. Rymbai, R.T. 1997. The changing pattern of the system of government of the Khasi-Jaintia from the customary (ancient) to the documentary (modern). Souvenir of Meghalaya Legislative Assembly Silver Jubilee Celebration (1972-1997).

[21]. Syiem, I.M and Soumen Sen ed. 1997. Women in Khasi Society in Women in Meghalaya. New Delhi: Daya Publishing House.

\section{Articles:}

[22]. Baruah, Apurba K. January 2004. Ethnic Conflicts and Traditional Self-Governing Institutions: a Study of Laitumkhrah Dorbar. North Eastern Institute for Development Studies (NEIDS).

[23]. Baruah, Apurba K. March 2003. Tribal Traditions and Crisis of Governance in North-east India, with Special Reference to Meghalaya. North Eastern Institute for Development Studies (NEIDS)

[24]. Sharma, Manorama. November 2004. Critically Assessing Traditions: The Case of Meghalaya. North Eastern Institute for Development Studies (NEIDS). Shillong, India.

\section{Other Sources:}

Constitution of Nongthymmai Dorbar Pyllun.

Interview:

1. Mr. D. Laloo, headman of Lawjynriew, on the $9^{\text {th }}$ November 2011 at 05:00 PM.

2. Mr. W.C. Kharkongor, an elder of Kharkongor clan, on the $19^{\text {th }}$ November 2011 at 10:30 AM.

3. Mr. W.B. Najer, headman of Lumdiengsoh, on the $7^{\text {th }}$ May 2012 at 06:15 PM.

4. Mr. V.G.K. Kynta, Advocate of KHADC, on the $26^{\text {th }}$ May 2012 at 08:20 AM.

5. Mr. H.S. Sohtun, headman of Lumiawblot, on the $12^{\text {th }}$ June 2012 at 05:00 PM.

6. Mr. C.K. Pasi, headman of Rynjah, on the $12^{\text {th }}$ June 2012 at 07:30 PM.

7. Mr. V.B. Khyriem, headman of Nongkhyriem, on the $14^{\text {th }}$ June 2012 at 08:30 AM.

8. Mr. P.S. Warjri, an Ex MDC of Nongthymmai, on the $16^{\text {th }}$ June 2012 at 07:20 AM.

9. Mr. K.P. Syiem, headman of Pohkseh, on the $16^{\text {th }}$ June 2012 at 09:30 AM.

10. Mr. L. Kharkongor, the present MDC of Nongthymmai, on the $22^{\text {nd }}$ June 2012 at 08:30 AM. 